\title{
Environmental justice as an act of love: A reflection on the agency of the youth on the Cape Flats
}

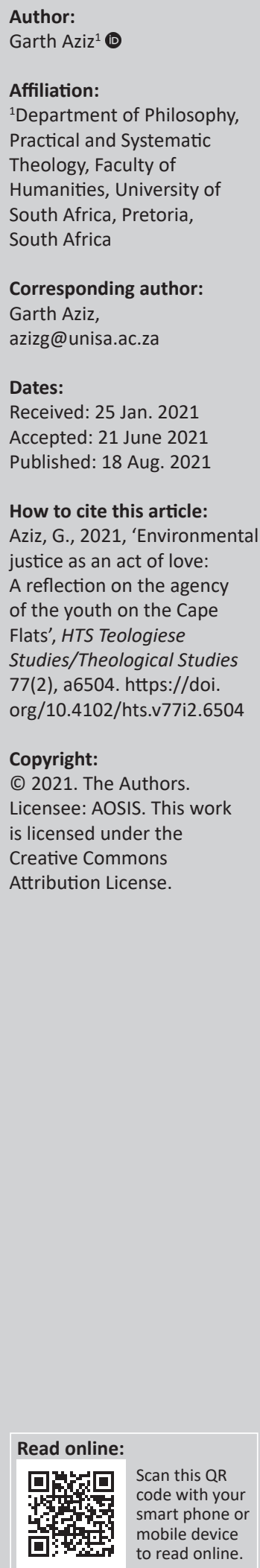

There has been visible evidence of youth activism regarding environmental consciousness on the global scene with some prominent voices amongst them. An increase in research on eco-theology has also been seen. Yet, it is easy to become fixated on environmentalism with regards to ozone depletion and greenhouse effects, and miss the various nuances of the movement. One such area relates to consumption and environmental justice, and that means not only for the global movement of environmentalism but more specifically in the local South African context.

Contribution: This article, therefore, will look at environmental justice as an act of love through the agency of the youth within the coloured community on the Cape Flats.

Keywords: youth; faith; consumption; environmental justice; youth ministry; Cape Flats; social justice.

\section{Introduction}

What is 'good life' as it relates to power, economics, environment, and the living realities of the individual (Wright 2011:163-164)? When talking about 'good life' in relation to power, economics, environment, and matters of social justice, it is nearly impossible to stand independent of one's faith and views of God. Environmental justice and consumption is an area that primarily affects the poor and the vulnerable, or people of colour (see s Wright 2011:164). They are not only the most exposed but also the most affected by environmental injustice. Progress and economic progress, do not favour everyone equally. In fact, they largely favour the rich and the powerful (Wright 2011:164).

The vast Youth of South Africa is multi-faceted and is representative of the contrast and diversity prevalent in South Africa. The country's youth population at 20 million, ages between 15 and 24, comprises 36\% of the total population (Statistics South Africa 2016). South Africa's youth population is rich in diversity and is comprised of many cultural groups - from indigenous African cultures to the cultures introduced through the slave trade and colonialism. South Africa has 11 official languages and its religious landscape consists of Christianity, Islam, Judaism, Hinduism, Buddhism, Traditional African Religion, and many smaller religious expressions (Statistics South Africa 2015:27). It, therefore, makes sense that we cannot speak of a homogenous youth with a homogenous experience, nor a homogenous South African culture, or South African expression. The South African context however, creates great opportunities for any form of work for the youth, which would include church-based youth ministries (Shepherd 2014:2-8).

There is no single or unified environmental movement in South Africa (Cock 2004:1; Death 2014:1217). Environmental issues are generally perceived to be the concern of the well-off white people (Cock 2004:19; Death 2014:1217; Neville 2010:5). It therefore becomes imperative that the environmental justice movement continues to take into consideration the threefold approach to justice $^{1}$ as well as attempt to create some form of unified action. Death (2014:1216), while not convinced that the vulnerable are unable to respond to environmental justice, mentions that there are arguments that tend to state that where underlying poverty exists and basic needs are left unmet, there is a lack of agency to focus on environmental matters. Cock (2004:1-2,17-18) argues that the movement is a bottom-up approach, one that is decentralised and is driven by the poor and marginalised. The environmental justice movement, therefore, comprises many different role

1.According to Cock (2004:2), the threefold approach to justice includes, the struggle against racism, the struggle against poverty and inequality and the struggle to protect the environment'.

Note: Special Collection: Youth, Faith, Climate Change and Environmental Consciousness: A Case for Sustainable Development, sub-edited by Jacques Beukes (University of Pretoria), Julianne Stork (Humboldt University, Berlin) and Ignatius Swart (University of the Western Cape). 
players from all segments of society and does not by virtue exclude any person or agency.

Kiarie (2020:9) recognises that the church has an important role to play in ecological justice through entering partnerships with organisations in the pursuit to denounce, 'the phenomenon of the rich becoming ever richer and stronger while they destroy the earth and further impoverish the poor, who become even more vulnerable, resulting in worsening injustice'. Wright (2011:179) also argues that the church or one's faith actions are 'based on the conviction of the integrity of creation, responsibility to steward God's creation, and conviction that justice, peace, and environmental protection are linked'. The good life, while there are various opinions and definitions, in this article refers to the interdependence of human and non-human beings where sacrifice and giving provide a deeper meaning to life's existential questions and experiences that consumption and acquisition can ever satisfy. The Bible consistently speaks about love as the most basic action whereby the world will know who the disciples of Jesus are (Jn 13:35). Furthermore, the Bible also states that if we love, we embody the principles of Jesus Christ, and thus we display our love for God and others (1 Jn 4:17-20). The fundamental premise that lays the foundation for Christians to love and respect the other, and by extension the nonhuman world - the embodiment of love as reflected in the principles of Jesus Christ.

This article, through a literature review, will address environmental justice and consumption through the lens of faith as an act of love, and that environmental justice is more than just recognising the delicate relationship between commodification and the market resulting in consumption. It will focus on the fact that the primary reason and motivation for environmental justice should be love for both the human and non-human world, which results in an embodied theology as a response to social justice.

The setting of this article is amongst the coloured youth of the Western Cape, who are a part of a predominantly fractured community that has or is experiencing various levels of poverty and injustice germinating from the oppressive apartheid system. The article seeks to address the connection between environmental justice and social justice, and the role that youth can play by contributing through faith actions.

\section{Why specifically the coloured community of the Cape Flats?}

Any theology should begin within a specific context especially if it is void of context, else it becomes too broad and general to have any significance to any person or even study. This study is located within the Cape Flats and more particularly the coloured community of the Cape Flats. The author's interest resides in the coloured community from the Cape Flats because it has a personal resonance with him as he grew up and spent most of his years in the Cape Flats. He also identifies as a person of colour, and a coloured African, in particular.

There is a general question of belonging to the coloured youth as the history is couched in politics and their identity is couched in uncertainty, and this has often resulted in a fragmented community. This basic premise, as the author would argue, is the most basic human need of love that is inherent in acceptance by the other and for the other. Apart from the identity of the coloured young person, which has many times been published as an individual that does not fit in or belong to any specific cultural or peoples group because of identity politics either during the apartheid or post-apartheid South Africa (McKaiser 2012), the lived realities are also uniquely shaped to recognise the need for social justice which is an important part of the discussion on environmental justice. This two-fold aspect of the coloured youth is therefore ideal to serve as not only a recipient of environmental justice, but also as an agent of environmental justice.

\section{Matters on identity}

Faith remains a significant factor in the lives of South Africans, more so in the lives of specific people's groupings such as the coloured community, irrespective of how superficial it may be in the lives of people (Oliver 2008; see also Statistics of South Africa 2015:28). The coloured community is defined as a mixed people's groups with various theories as to its origins from miscegenation, the slave trade, the original people's group of South Africa, a political creation, and of course as an ever-evolving creolisation (Adhikari 2005, 2008; Amoateng \& Richter 2007:2; Calix 2013:48; Klaasen 2016:5). While this article is not aimed at arguing the origins of the coloured community, it is noticeable that this community is not homogenous but one that is filled with nuance and variety from the clothing worn to the dietary expressions, and even religious expression. However, race and identity cannot be separated, and in the South African context identity is deeply rooted in the apartheid narrative of South Africa (Klaasen 2016:2). The history of the coloured people in South Africa has led to uncertainty and has resulted in a fragmented community where the youth may suffer from low self-esteem and the need for social recognition because of 'a combination of deteriorating social structure and bonds, low economic status and inequality of opportunity' (Bowers DuToit 2014:3). It is interesting to note the resurgence and the embracing of 'being coloured' especially by the younger generations as is evidenced through personalities in the sporting industry as well in the media. The representative of which are the famous personalities such as Wayde Van Niekerk, Cheslin Colbe, Nizaam Carr, YoungstaCPT, AKA, and Tamaryn Green, just to mention a few. There are also proactive NGOs and groups such as Vannie Kaap, and Coloured Mentality that not only inform but also embrace the coloured identity. Yet, despite the resurgence of embracing the coloured identity, the most basic premise, the author argues, is the basic human need of love that is reflected in acceptance by the other and for the other. 


\section{Aspects of social justice}

The youth of the Cape Flats are predominantly Coloured Africans and Black Africans (Bray et al. 2012:27). The youth population of Cape Town is 651856 and only represents 3/5th of the total Cape Town population. The youth population of Cape Town is mainly Black African at $46 \%$, comprising Coloured African, (40\%) White African (13\%) and Indian/ Asian African (1\%). The most dominant spoken language is IsiXhosa at $41 \%$, Afrikaans at $30 \%$, and English at $26 \%$ (Statistics of South Africa 2016; see also Bray et al. 2012:27). Forty-two per cent of the youth live in income-poor households and $14 \%$ live in overcrowded homes. The unemployment rate amongst the youth is $46 \%$ (Statistics of South Africa 2016). Statistically, the youth of Cape Town may be experiencing a crisis. There have been numerous researches on the challenging lived realities of the youth from Cape Town from witnessing, perpetrating and being affected by violent crimes, substance abuse, risky sexual activities (Francis et al. 2019); unemployment (Cloete 2015; Swart 2018); gangsterism (Bowers Du Toit 2014); broken and dysfunctional family settings (Dames 2014); poverty (Bray et al. 2012); and substantial levels of fear and anxiety (Dickie 2020).

Many of the experiences listed above regarding the youth does overlap with Death's (2014:1227) definition of environmental justice where one's life is affected by the lack of safety, security, and providence because of systemic infrastructural anomalies. Furthermore, one needs to just drive around the various townships of Cape Town to witness the high level of illegal dumping and pollution (Death 2014:1228), possibly a result of the high level of consumption (Deane-Drummond 2006:303), which has a direct impact on the environment. Localised injustices on the social and environmental level gives birth and momentum to movements such as the environmental justice movement (Cock 2004; Scott \& Barnett 2009:373).

\section{Environmental justice and consumption}

Environmental justice is but one of many social movements that have grown in prominence since the 1990s (Scott \& Barnett 2009:374). While Cock (2004:5) sees environmental justice as 'questioning the market's ability to bring about social or environmental sustainability'. Deane-Drummond (2006:295) defines environmental justice as 'an unequal burden of environmental harms on poorer human (and by extension, non-human) communities'. In a similar understanding of environmental justice, Wesley (2012:81) sees it as all-encompassing and affects all of creation animate and inanimate. Environmental justice affects everyone and is really about the daily injustices that are so prominent to people living on the Cape Flats. Both Cock (2004:2) and Death (2014:1228) believe that the struggles for service delivery is often not about service delivery but is in fact matters of environmental justice. This opinion is significant as most of the protest actions in South Africa resides around the call for better service delivery and the right to access socio-economic resources such as housing, sanitation, improved and reliable energy and transportation, and improved health (Neville 2010:8). Deane-Drummond (2006:302) acknowledges that, 'Extreme poverty, social exclusion and environmental injustice appear in tandem'.

Environmental justice asks a most basic question, 'What is morally correct?' and how is all life on this planet valued and protected from violations that extend from the need to amass 'wealth, power and technology' (Cock 2004:5). Cock (2004:5) correctly identifies that the need for environmental justice is secured in the Bill of Rights of the South African constitution which recognises the inalienable right to life for every person as well as the right to socio-economic resources, adequate housing and education so that these may contribute to a meaningful life so that the most basic of human needs are met.

\section{Death (2014) argues that the:}

$[D]$ aily struggles over issues like housing, water, electricity, land, transport and so on clearly are environmental struggles ... issues which have come to be referred to through the shorthand of 'service delivery' but which are actually about the provision of clean water, decent sanitation, reliable and affordable electricity, safe roads, and so on. (p. 1227)

Death (2014:1228) further argues that poor housing conditions lead to various environmental matters such as pollution, unclean water, poor sanitation, health-related problems, and ecological problems. Poor housing is a stark reality and reminder of the apartheid laws used to oppress people of colour and still exists as a reminder of the apartheid spatial planning that was used to separate people of colour from white people where many still live in informal settlements. Death (2014:1228), therefore states, 'housing is an obvious environmental issue: insecure housing means an insecure environment, and poorly planned and located housing causes serious ecological problems'. The idea that Death builds on is seen in the discussion by Cock (2004) also who argues that:

This embryonic environmental justice movement is bridging ecological and social justice issues in that it puts the needs and rights of the poor, the excluded and the marginalised at the centre of its concerns. (pp. 1-2)

While environmental justice is gaining momentum especially in the South African context, the most basic premise is social justice, which attends to meet the human needs, the rights of the majority, and the protection of the environment, the non-human community (Deane-Drummond 2006:295, 303).

\section{Love: A most basic premise}

There is a general perception that human greed and the overutilisation of resources are the main drivers of environmental decay and injustices (Neville 2010:21). Corporations in both governmental agencies and the private sector need to address matters of environmentalism (Neville 2010:5). Much of the inequalities discussed above are further exacerbated by corporations widening and even creating 
inequalities amongst people by 'increasing commodification of natural resources' (Cock 2004:30). Yet, there should be a most basic response in seeking to alleviate poverty and to meet the needs of the most disadvantaged in society (DeaneDrummond 2006:302-303). Corporations have a responsibility and a role in addressing environmental justice. They should not be a part of the problem in creating or perpetuating social and environmental injustices (Cock 2004:30; DeaneDrummond 2006:297; Scott \& Barnett 2009:374).

Deane-Drummond (2006:298) asks specifically how the market, production and consumption reflects Christian perspectives and ideals. Deane-Drummond (2006:298) argues that if we are to recognise the example of Jesus Christ then there is a need to recognise social justice as it extends to the human and non-human communities. There is a definite response that is Christian, a response birthed out of love for the other and should be enacted by the Christian community if it is to express the ideals of Jesus Christ.

\section{What are faith actions?}

This article is discussed within the Christian epistemology as a response to environmental justice. While environmental justice is not exclusively in the domain and limited to Christian epistemology, Wright (2011:181) believes though, that a Christian response is sufficient to address matters of environmental justice. Harper and Kennealy (2009) list several activities that can help in the development and discussion of environmental justice, which the author calls faith actions, such as worship, religious education, spiritual practices, and collaboration with leaders in the environmental justice movements as well as advocacy groups. Other activities are related to how people can conserve but also use energy, food and water, and reduction of waste and pollution.

Faith actions, in this article, is any action irrespective of how small that arises from one's belief in God - essentially an embodied theology - a virtue that recognises justice as a moral and Christian response (Deane-Drummond 2006:297; Harper \& Kennealy 2009:620). Additionally, these actions could also be creatively expressed in liturgies, rituals, feasts, and even prayers (Wesley 2012:83). Furthermore, it is difficult to discuss faith actions apart from the role of the church as individual and corporate faith actions should not be separated. The approach that is argued for is a move away from individualistic piety that seeks only personal salvation but one that acknowledges the communal nature and connection between all beings, a self-giving and sacrifice for those who have less out of the abundance of those who have much (Deane-Drummond 2006:299-300; Wesley 2012:84). Faith actions, in this sense, are actions resulting out of love for the other as well as the non-human beings (Deane-Drummond 2006:299).

Kiarie (2020) argues that the church has a definitive role to play in the environmental movement whereby it not only advocates for responsible stewardship of the earth, but also to educate people on the role they should play considering the mandate that God has given to look after the earth. Kiarie (2020:7) calls a failure to protect the earth, sin against God and nature. Wright (2011:182) expands on the concept by saying that $\sin$ is also extended when there is the oppression of people, in particular, the 'powerless'. The church may be able to contribute positively to the conversation, but also through action if it consistently practices these beliefs whether through rituals as acts of worship, education, and being advocates of environmental justice (Harper \& Kennealy 2009:625). Neville (2010:29), too, notes that religious and faith leaders have a role to play in the environmental discussion, especially in offering accurate and relevant information to people. Neville $(2010: 5,21)$ notes that often the belief of deteriorating environmentalism is because of God's will and the punishment of $\sin$.

\section{A way forward}

The poor and the marginalised need not be passive recipients of injustice, and reap the unfortunate consequences of massive consumption by the big corporates as argued by Wright (2011:164). On the contrary, the poor and the marginalised, because of their localised knowledge and experience, are ideally suited to participate in the development and execution of environmental justice and by doing so validates their agency and need for meaningful change. In light of the context, knowledge, and experience of the poor and marginalised, three aspects worthy of discussion as a way forward, as developed in this article, are the distribution of relevant and accurate information, the right to protest actions, and living an embodied faith.

\section{The distribution of relevant and accurate information}

One significant reason for the lack of engagement on matters of environmental justice is that there is a shortage of relevant and useful information around environmentalism in the African context which often results in ineffective responses and change (Neville 2010:5). Firstly, there is a need to provide relevant information to common persons. The church must become a vehicle for the distribution of such information as the church remains an institution that garners much trust with and amongst people (Burger, Louw \& Van der Watt 2010:68; Nieman 2010:42). Secondly, while it is important to consider and not exclude the knowledge and experiences of a common individual, instead, the knowledge and information of the common person should be validated against factual knowledge and information (Scott \& Barnett 2009:381) and in doing so legitimises the life and the experiences of those affected. This process of taking the voice of the person seriously should allow spaces within churches for people to talk about matters regarding social justice and the related trauma arising from these experiences. These tools, the experience and the knowledge especially scientific knowledge of a common person,become great tools for holding the government and private sectors accountable 
(Scott \& Barnett 2009:381) whether through the creation of charters to holding corporations accountable or actions for sustainable development (Wright 2011:183-184).

\section{Protest action}

It makes complete sense that the youth from the Cape Flats could be a dominant voice in environmental justice as a voice emerging from the margins but also a voice that is directly affected by environmental injustices (Cock 2004:1, 5). Environmental justice movement is a grassroots movement, most often one that is decentralised with no established leadership (Cock 2004:18). Therefore, more emphasis must be placed on the effects of environmentalism and environmental justice, and how this has a direct impact on people's livelihoods and lives (Neville 2010:5).

While there may not be explicit movements and actions by the youth under the banner of environmentalism, the above discussion has shown that actions within the various protestations can indeed be listed as environmental actions (Cock 2004:2-3). Perhaps, it should be our duty as youth ministry practitioners to break the stigma that could be attached to an environmentalist activist. In the end, a protestation and environmental activism is merely a means of redistributing power from the corporates to that of the common person. Activism and protestation in this case would also include discussions and debates at all levels of society (Enslin 2003:78). It becomes important that this protest action is not only in the domain of the young person but should also be coordinated by the young as it remains a world that they will inherit from those who hold the power and decisions. Further examples of protest actions could include advocacy whereby individuals and groups can meet and discuss opportunities with local communities, organisations, and elected officers of communities as well as partner with grassroots organisations within such communities (Harper \& Kennealy 2009:625).

\section{Embodied faith}

When discussing matters of environmentalism and environmental justice there is a need to include and engage faith and spiritual leaders (Neville 2010:21) and collaboration with any organisations that seeks 'to create a world of peace and justice ... those who are part of salvation ... because they are finding life-giving counter-arguments to the present system'. (Wright 2011:184; see also, Wesley 2012:83). Furthermore, caring for the environment is part of stewardship towards the earth, and through sensitive communication, this may be an area for meaningful engagement (Neville 2010:21). As previously mentioned, churches and faith leaders have a tremendous role within communities as they can move people to action because of the trust between faith leaders and the community (Burger et al. 2010:68; Nieman 2010:42). While it is meaningful to recognise personal faith and piety, the church should facilitate a process that would allow for a movement away from individual sanctification only to one where the faith of the person is realised within the community and the lived realities of people. After all, an embodied faith, which is a life of public worship, is one that is communal and something that youth are not afraid to engage in as is evidenced in the many public movements within the contemporary context. Furthermore, by creating opportunities for an embodied faith allows also for a redistribution of power from the religious leaders to the ones practising their faith in everyday moments.

\section{Conclusion}

Environmental justice should not just be a scientific or economic discussion. It should also involve the humanities and in this case the theological. Environmental justice, according to this article, is fundamentally an act of love towards all forms of creation, both human and non-human. The article has also continued the discussion that sought not to divorce environmental injustices from social injustices, and that indeed these two aspects are related and oftentimes synonymous. The idealism and energy of the youth allow for a significant bottom-up approach to challenge the government and corporates to realise their responsibility to environmental justice. Finally, an approach to active environmental justice is nothing less than an act of love that is enveloped in an embodied faith and is expressed in every aspect of society.

\section{Acknowledgements Competing interests}

The author declares that he has no financial or personal relationships that may have inappropriately influenced him in writing this article.

\section{Author's contributions}

G.A. is the sole author of this article.

\section{Ethical considerations}

This article followed all ethical standards for research without direct contact with human or animal subjects.

\section{Funding information}

This research received no specific grant from any funding agency in the public, commercial or not-for-profit sectors.

\section{Data availability}

Data sharing is not applicable to this article as no new data were created or analysed in this study.

\section{Disclaimer}

The views and opinions expressed in this article are those of the author and do not necessarily reflect the official policy or position of any affiliated agency of the author. 


\section{References}

Adhikari, M., 2005, Not white enough, not black enough: Racial identity in the South African coloured community, Double Story Books, Cape Town.

Adhikari, M., 2008, 'From narratives of miscegenation to post-modernist re-imagining Toward a historiography of coloured identity in South Africa', African Historical Review 40(1), 77-100. https://doi.org/10.1080/17532520802249472

Amoateng, A.Y. \& Richter, L., 2007, 'Social and economic contexts of families and households in South Africa', in T.B. Heaton \& A.Y. Amoateng (eds.), Families and households in post-apartheid South Africa: Socio demographic perspectives, pp. 1-26, HSRC Press, Cape Town.

Bowers du Toit, N.F., 2014, 'Gangsterism on the Cape Flats: A challenge to "engage the powers"', HTS Teologiese Studies/Theological Studies 70(3), Art. \#2727, 1-7. https://doi.org/10.4102/hts.v70i3.2727

Bray, R., Gooskens, I., Kahn, L., Moses, S. \& Seekings, J., 2012, Growing up in the new South Africa: Childhood and adolescence in post-apartheid Cape Town, HRSC Press, Cape Town.

Burger, R., Louw, M. \& Van der Watt, C., 2010, 'The challenge of poverty and social exclusion in post-apartheid South Africa: Considering the potential role of religious groups', in I. Swart, H. Rocher, S. Green \& J. Erasmus (eds.), Religion and social development in post-apartheid South Africa, pp. 61-74, SunPress, Cape Town.

Calix, K.R., 2013, 'Wie is ek? Coloured identity and youth involvement in gangsterism in Cape Town, South Africa', Senior Honours thesis, Stanford University.

Cloete, A., 2015, 'Youth unemployment in South Africa: A theological reflection through the lens of human dignity', Missionalia 43(3), 513-525. https://doi. org/10.7832/43-3-133

Cock, J., 2004, Connecting the red, brown and green: The environmental justice movement in South Africa, Centre for Civil Society, University of KwaZulu-Natal, Durban.

Dames, G.E., 2014, A contextual transformative practical theology in South Africa, AcadSa, Parow.

Deane-Drummond, C., 2006, 'Environmental justice and the economy: A Christian theologian's view', Ecotheology 11(3), 294-310. https://doi.org/10.1558/ ecot.2006.11.3.294

Death, C., 2014, 'Environmental movements, climate change, and consumption in South Africa', Journal of South African Studies 40(6), 1215-1234. https://doi.org/ 10.1080/03057070.2014.964494

Dickie, J.F., 2020, 'The practice of biblical lament as a means towards facilitating authenticity and psychological well-being', Pastoral Psychology 69, 523-537. https://doi.org/10.1007/s11089-020-00928-z
Enslin, P., 2003, 'Citizenship education in Post-apartheid South Africa' Cambridge Journal of Education 33(1), 73-83. https://doi.org/10.1080/ 0305764032000047513

Francis J.M., Myers B., Nkosi S., Petersen W.P., Carney T., Lombard C. et al., 2019, 'The prevalence of religiosity and association between religiosity and alcohol use, other drug use, and risky sexual behaviours among grade 8-10 learners in Western Cape, South Africa', PLoS One 14(2), e0211322. https://doi.org/10.1371/ journal.pone.0211322

Harper, F. \& Kennealy, S., 2009, 'Greening our faith: Putting belief into action', Anglican Theological Review 91(4), 619-625.

Kiarie, G.K., 2020, 'Environmental degradation: What is the role of the church in environmental conservation in Kenya from 1963-2019?', Church History Society of Southern Africa 46(2), 1-12. https://doi.org/10.25159/2412-4265/6762

Klaasen, J., 2016. 'Identity, race and faith: The role of faith in post-Apartheid South Africa', HTS Teologiese Studies/Theological Studies 72(2), a3861. https://doi. org/10.4102/hts.v72i2.3861

McKaiser, E., 2012, 'Not white enough, not black enough', NY Times, 15 February 2012 viewed 09 September 2016, from http://latitude.blogs.nytimes.com/2012/02/15/ in-south-africa-after-apartheid-colored-community-is-the-big-loser/.

Neville, L., 2010, South Africa talks climate: The public understanding of climate change, BBC World Service Trust, London.

Nieman, A., 2010, 'Churches and social development in South Africa: An exploration', in I. Swart, H. Rocher, S. Green \& J. Erasmus (eds.), Religion and social development in post-apartheid South Africa, pp. 37-44, SunPress, Cape Town.

Oliver, E., 2008, 'South Africa: From Calvanistic exclusivism to religious freedom 1652-2008', Church History Society of Southern Africa 281, 29.

Scott, D. \& Barnett, C., 2009, 'Something in the air: Civic science and contentious environmental politics in post-apartheid South Africa', Geoforum 40(3), 373-382. https://doi.org/10.1016/j.geoforum.2008.12.002

Shepherd, N., 2014, 'Being a Christian youth worker: Finding ourselves by losing ourselves', in S. Nash \& J. Whitehead (eds.), Christian youth work in theory and practice, pp. 1-15, SCM Press, London.

Statistics South Africa, 2015, General household survey 2015, viewed January 2021, from http://www.statssa.gov.za/publications/P0318/P03182015.pdf.

Statistics South Africa, 2016, South African Community Survey 2016, viewed January 2021, from https://youthexplorer.org.za/profiles/municipality-CPT-city-of-cape-town/.

Swart, I., 2018, 'Youth marginalisation as a faith-based concern in contemporary South African society: Introducing a research contribution', HTS Theological Studies 74(3), 1-8. https://doi.org/10.4102/hts.v74i3.5253

Wesley, A.K., 2012, 'Eco-justice: A reflection', Asia Journal of Theology 26(2), 80-85.

Wright, N.G., 2011, 'Christianity and environmental justice', CrossCurents 61(2), 161-190. https://doi.org/10.1111/j.1939-3881.2011.00174.x 